\title{
Liver lysosomes in protein-starved rats
}

\author{
By V. NINJOOR, S. SAROJA, S. R. PADWALDESAI, \\ P. L. SAWANT, U. S. KUMTA AND A. SREENIVASAN \\ Biochemistry $\mathfrak{F}^{\circ}$ Food Technology Division, Bhabha Atomic Research Centre, \\ Trombay, Bombay 74, India
}

(Received I 8 November I968-Accepted I4 April I969)

\begin{abstract}
1. The feeding of a protein-free diet to adult rats trained to consume their whole day's food in $2 \mathrm{~h}$ changed the characteristics of hepatic lysosomes immediately upon the onset of protein deficiency combined with calorie deficiency.

2. The nature of the alterations in the characteristics of liver lysosomes were deduced from the faster release of enzymes, swelling of membranes and a change in the sedimenting properties. Purified lysosomes from pooled livers from a group of rats fed on a protein-free diet for only a day, showed marked differences when compared with lysosomes from normal rats. When lysosomes were suspended in sucrose solutions of two different molar concentrations, the release of acid phosphatase occurred at a faster rate in liver lysosomes of protein-starved rats than in those of normal ones. The light-scattering characteristics of the suspensions suggested the presence of swollen lysosomes in livers of rats fed on a protein-free diet and normal lysosomes in the livers of control rats.

3. In homogenate of liver from rats fed on a protein-free diet for I I days the levels of cathepsin and acid ribonuclease showed a five- to six-fold increase in the free specific activities when compared with those of controls.

4. The role of lysosomes is discussed with reference to the accumulation of hydrolytic endproducts and liver autolysis during protein starvation.
\end{abstract}

The relationship between diet and liver metabolism has been studied extensively at the cellular and subcellular levels (Rappaport, 1963). The properties of mitochondria and endoplasmic reticulum in protein malnutrition have been examined with reference to oxidative phosphorylation and protein synthesis respectively (Williams, 196r; Waterlow, 1959; Narasinga Rao \& Radhakrishnan, I966). However, little information is available on the structure and function of lysosomes under this state of nutritional stress. De Duve (1959) and Novikoff (I961) have reviewed the importance of lysosomes in physiopathological autolysis, intracellular digestion and in the engulfing process.

In fasting animals, and especially during kwashiorkor, the Golgi complex is rarely visible (Camain, Rouiller \& Dupin, 1959), but the region of the cell where it is normally found is occupied by masses of dense material that correspond to hypertrophied lysosomes filled with lipofuscin, described by Essner \& Novikoff (I96r) and Gadrat, Panel, Guilhem \& Izard (1960). During recovery from kwashiorkor, the Golgi complex reappears near both the bile capillaries, and pigment is deposited (Camain et al. 1959). Novikoff ( 1961 ) has stated that the Golgi complex can disappear in certain pathological states and reappear during regeneration as the ergastoplasm does. These histochemical studies suggest a close relationship between the lysosomes, the pigments and the Golgi apparatus. Biochemical characterization of lysosomes (de Duve, 1959) and a method for their isolation (Sawant, Shibko, Kumta \& Tappel, 1964) provided scope for detailed studies on these relationships. 
The purpose of the present communication is to report on the status of lysosomebound enzymes in livers from protein-starved rats which were trained to consume the entire day's food in a limited period of $2 \mathrm{~h}$ (spaced-feeding). This study was also aimed at understanding the effect of protein deficiency along with calorie deficiency on liver lysosomes.

\section{EXPERIMENTAL}

\section{Diets, animals and their training}

Animals, the method of their training and the diets were as described previously (Padwaldesai, Ninjoor, Ramakrishnan, Sawant, Kumta \& Sreenivasan, 1969). In some experiments animals were killed after I day's feeding and in other experiments after I I days.

\section{Tissue preparation and enzyme methods}

Preparation of tissue homogenates. Rats were killed by decapitation and the livers were immediately excised, washed, blotted, weighed and transferred to a $0.25 \mathrm{M}$ solution of sucrose maintained at $0^{\circ}-4^{\circ}$. The livers were chopped finely and a $10 \%$ homogenate was prepared in $0.25 \mathrm{M}$-sucrose $(\mathrm{pH} 7.0$, containing $0.00 \mathrm{r}$ M-diaminoethanetetraacetic acid disodium salt). The homogenization was performed in a glass homogenizer tube, using a Teflon pestle. The homogenizer was precooled to $0^{\circ}$ and thereafter kept in ice-water. The tissue was homogenized by passing the tube up and down four times while the pestle was rotated at about $1500 \mathrm{rev} / \mathrm{min}$. Homogenates of liver were filtered through two layers of surgical gauze.

Enzyme substrates. Haemoglobin was prepared according to the method of Anson (1938) from ox blood. The sodium salt of RNA was obtained from Calbiochem, Los Angeles, USA; the sodium salt of $\beta$-glycerophosphoric acid was obtained from $\mathrm{E}$. Merck, Germany; crystalline 2-hydroxy, 5-nitrophenyl sulphate, dipotassium salt was obtained from Koch-Light Laboratories, England.

Determination of enzyme activity. Two forms of enzymic activity were measured to assay lysosomal enzymes (de Duve, 1959). The free enzyme activity was determined under conditions which maintained the integrity of particles as much as possible, namely, by means of a $10 \mathrm{~min}$ assay at $37^{\circ}$ with the same sucrose concentration in the substrate as in the suspension of homogenate or isolated lysosomes. The total activity was determined after freezing and thawing the homogenate several times and after treatment of diluted homogenate with Triton X-I0o at a final concentration of $0.1 \%$.

With the exception of cathepsin, each enzyme unit was defined as the amount of enzyme that catalysed the hydrolysis of I $\mu$ mole of substrate per min under the conditions stated. The unit of cathepsin activity was defined as the amount that liberated I $\mu$ mole tyrosine (or substances of equivalent optical density) per min. For convenience the results were expressed as milli-units.

Acid phosphatase $\left(E C C_{3.1} \cdot 3 \cdot 2.\right)$, aryl sulphatase $\left(E C_{3} . \mathbf{I}_{\ldots} \ldots\right.$ ), acid ribonuclease $(E C 2.7 \cdot 7.16)$ and cathepsin $(E C 3.4 .4 .9)$ activities were determined according to the methods reported by Sawant, Shibko, Kumta \& Tappel (1964).

Measurement of hydrolytic end-products. Amino acids and peptides expressed as tyrosine equivalents and inorganic phosphate were estimated in the $10 \%$ 
trichloroacetic acid supernatant fraction from the homogenate according to the methods of Miller (1959) and Lowry, Roberts, Wu, Hixon \& Crawford (I954) respectively. Samples from the acid supernatant fraction were treated with phenol reagent for the measurement of tyrosine and with ascorbic acid molybdate reagent for phosphate estimation. Compounds possessing absorbancy at $260 \mathrm{~nm}$ were measured spectrophotometrically in the supernatant fraction obtained after addition of $10 \%$ perchloric acid containing $0.25 \%$ uranium acetate, and are expressed as equivalent of adenylic acid.

The method of Sawant, Shibko, Kumta \& Tappel (1964) was followed to isolate purified lysosomes from normal rat liver. The pooled livers of rats from groups 2 and 3 were assumed to be normal livers, since both groups served as controls in a single day feeding. The above method was modified after the density-gradient step in the original procedure for isolating lysosomes from livers pooled from rats after only one feed of the protein-free diet. It involves removal of the sediment at $4000 \times \mathrm{g}$ (Io min) and isolation of purified lysosomes from the supernatant fraction by centrifugation at $8000 \times \mathrm{g}(20 \mathrm{~min})$. This is necessary to achieve their maximum sedimentation and to avoid contamination from other subcellular organelles which would interfere in subsequent studies.

Purified lysosomes were suspended in $0.7 \mathrm{M}$ - or in $0.25 \mathrm{M}$-sucrose. These included lysosomes from rats of groups 2 and 3 (normal) and group I (protein-starved). Light-scattering of the suspensions was measured at room temperature $\left(26^{\circ}-28^{\circ}\right)$ as a function of osmotic pressure and time by determining the absorbancy at $540 \mathrm{~nm}$. The protein concentration in all the suspensions was adjusted to $\mathrm{I} \mathrm{mg} / \mathrm{ml}$.

The percentage availability of acid phosphatase was calculated as the ratio of free to total activity. This was determined from the purified lysosomes suspended in $0.25 \mathrm{M}-$ and $0.7 \mathrm{M}$-sucrose incubated at different time intervals.

RESULTS

\section{Enzyme levels}

Table I shows free and total activities of cathepsin, acid ribonuclease, acid phosphatase and aryl sulphatase from rat liver homogenates. These results show increases of from five- to six-fold in free specific activities of cathepsin and acid-ribonuclease in liver from rats given the protein-free diet for II days.

\section{Accumulation of hydrolytic end-products}

The values for tyrosine equivalent, $E^{260}$ absorbing compounds and inorganic phosphate in the acid supernatant fraction are shown in Table 2. The level of phosphate remained the same in all the groups. However, tyrosine equivalents and $E^{260}$ absorbing substances increased in the livers from protein-starved rats. 


\section{Table I. Lysosomal enzymes* in livers from rats after i I days of spaced-feeding}

(Enzyme assays were performed on freshly prepared homogenate suspensions for free activities and repeated for total activities after the suspension had been frozen and thawed several times and after addition of 'Triton X-100 (0.1\%). The incubation mixture consisted of $0.5 \mathrm{ml}$ enzyme suspension and $0.5 \mathrm{ml}$ of substrate. For controls, substrate was added after the reaction was stopped. Reaction time was ro $\mathrm{min}$ )

\begin{tabular}{|c|c|c|c|c|c|c|c|c|}
\hline \multirow[b]{2}{*}{ Group no. } & \multicolumn{2}{|c|}{ Cathepsin } & \multicolumn{2}{|c|}{ Acid ribonuclease } & \multicolumn{2}{|c|}{ Acid phosphatase } & \multicolumn{2}{|c|}{ Aryl sulphatase } \\
\hline & Total $\uparrow$ & $\begin{array}{l}\text { Bound } \\
(\% \text { total })\end{array}$ & Total $\uparrow$ & $\begin{array}{l}\text { Bound } \\
(\% \text { total })\end{array}$ & Total $\uparrow$ & $\begin{array}{l}\text { Bound } \\
(\% \text { total) }\end{array}$ & Total $\uparrow$ & $\begin{array}{l}\text { Bound } \\
\text { (\% total) }\end{array}$ \\
\hline $\begin{array}{l}\text { (protein-free } \\
\text { diet) }\end{array}$ & $\begin{array}{c}18 \cdot 8 \pm I \cdot 9 \\
(13 \cdot 2 \pm 2 \cdot 0)\end{array}$ & $29 \cdot 8$ & $\begin{array}{c}76 \cdot 0 \pm 10 \cdot 6 \\
(50 \cdot 0 \pm 5 \cdot 6)\end{array}$ & $34 \cdot 2$ & $\begin{array}{c}71 \cdot 0 \pm 6.4 \\
(13.6 \pm 3.7)\end{array}$ & $80 \cdot 8$ & $\begin{array}{c}3.9 \pm 0.52 \\
(0.7 \pm 0.15)\end{array}$ & $82 \cdot 0$ \\
\hline 2 (basal diet) & $\begin{array}{l}I 7.9 \pm 0.94 \\
(1.4 \pm 0.56)\end{array}$ & $92 \cdot 2$ & $\begin{array}{l}82.8 \pm 13.6 \\
(10.8 \pm 1 \cdot 6)\end{array}$ & 87 & $\begin{array}{l}85 \cdot 5 \pm 4 \cdot 3 \\
(9 \cdot 9 \pm 1 \cdot 4)\end{array}$ & $88 \cdot 4$ & $\begin{array}{c}4.5 \pm 0.6 \\
(0.2 \pm 0.06)\end{array}$ & $95 \cdot 5$ \\
\hline $3 \begin{array}{r}\text { (pair-fed } \\
\text { control) }\end{array}$ & $\begin{array}{l}\text { I } 7.8 \pm 1.89 \\
(3.5 \pm 0.52)\end{array}$ & $80 \cdot 3$ & $\begin{array}{c}74 \cdot 0 \pm 4 \cdot 6 \\
(9 \cdot 6 \pm I \cdot 2)\end{array}$ & 87 & $\begin{array}{c}89 \cdot 0 \pm 7 \cdot 4 \\
(11 \cdot 3 \pm 3 \cdot 5)\end{array}$ & $87 \cdot 3$ & $\begin{array}{c}4.4 \pm 0.37 \\
(0.3 \pm 0.12)\end{array}$ & $93 \cdot 2$ \\
\hline
\end{tabular}

* Unit of activity is expressed as n-moles of substrate hydrolysed/min per $\mathrm{mg} N$. $†$ Mean values with their standard errors.

Values in parentheses denote free activity. The total activity of the four enzymes studied was not changed $(P>0.05)$ whereas differences in free activity between groups $I$ and 2 and groups $I$ and 3 for cathepsin and ribonuclease were significant $(P<0.01)$, as were those for aryl sulphatase and acid phosphatase $(P<0.05)$.

Table 2. Hydrolytic end-products of livers from rats after I days of spaced-feeding

\section{Group no.}

1 (protein-free diet)

2 (basal diet)

3 (pair-fed control)
Amino acids and peptides*

$$
\begin{aligned}
& 3.7 \pm 0.56 \\
& 1.8 \pm 0.30 \\
& 1.5 \pm 0.40
\end{aligned}
$$

$E^{260}$

absorbing
compounds $\uparrow$

$55 \pm 6 \cdot 1$

$32 \pm 2 \cdot 3$

$30 \pm 2 \cdot 7$
Inorganic phosphorus $f$

$650 \pm 152$

$575 \pm 255$

$566 \pm 58$

Mean values are given with standard errors.

* Expressed as $\mu$ moles $/ \mathrm{mg} \mathbf{N}$ of tyrosine equivalents.

tExpressed as $\mathrm{n}$-moles/mg $\mathrm{N}$ of adenylic acid equivalents.

$\ddagger$ Expressed as n-moles of $P / \mathrm{mg} N$.

Difference between groups $I$ and 2 and groups $I$ and 3 for amino acids and peptides, $P<0.05$, $E^{260}$ absorbing compounds $P<0.01$, inorganic phosphorus $P<0.01$.

\section{Light-scattering property of purified lysosome and availability of acid phosphatase}

Swelling properties and kinetics of availability of acid-phosphatase from lysosomes of livers from control (groups 2 and 3 ) and protein-starved (group I) rats are shown in Figs. I and 2. In hypotonic medium ( $0.25 \mathrm{M}$-sucrose) absorbancy at $540 \mathrm{~nm}$ of lysosomal suspension prepared from normal liver decreased as a function of time at room temperature. However, at both levels of sucrose, the absorbancy of lysosomal suspension from the livers from protein-starved rats decreased initially and remained constant as the time progressed. Acid phosphatase from the livers of protein-starved rats became available at a faster rate in both media than that from normal liver. 




Fig. 1

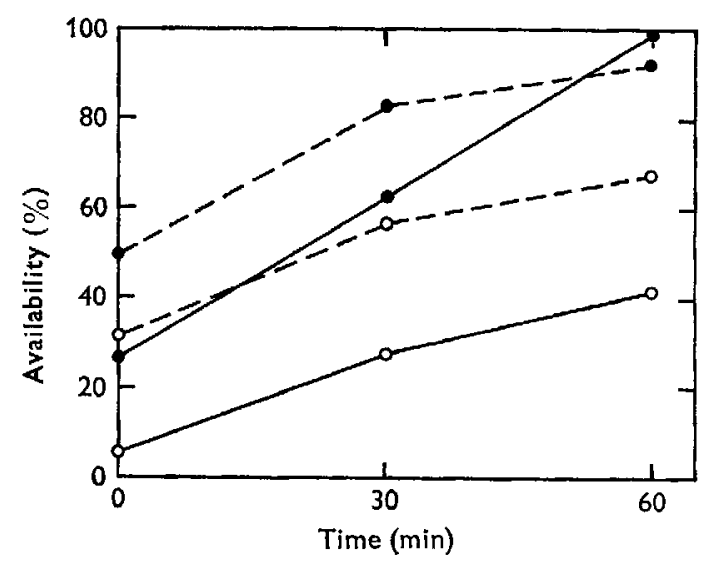

Fig. 2

Fig. I. Light-scattering properties of isolated lysosomes from livers of five rats killed after 1 day's spaced-feeding. - - $0.25 \mathrm{M}$-sucrose; $\mathrm{O}-\mathrm{O}, 0.7 \mathrm{M}$-sucrose (groups 2 and 3 , spaced-fed rats given protein-containing diet); $\times---\times, 0.25 \mathrm{M}$-sucrose and $0.7 \mathrm{M}$-sucrose (group I, given protein-free diet).

Fig. 2. Availability of acid phosphatase from isolated lysosomes from livers of five rats killed after I day's spaced-feeding. - - O O - - 0 , spaced-fed rats given protein-free diet, lysosomes suspended in $0.25 \mathrm{M}$-sucrose and $0.7 \mathrm{M}$-sucrose respectively (group I); $\mathrm{O}-\mathrm{O}$, spaced-fed rats given diet containing protein, lysosomes suspended in $0.25 \mathrm{M}-$ sucrose and $0.7 \mathrm{M}$-sucrose respectively (groups 2 and 3 ).

\section{DISCUSSION}

The increase in the free specific activities of cathepsin and acid ribonuclease in liver from rats given a protein-free diet for II days indicated preferential release of these two enzymes, probably owing to changes in physicochemical properties of lysosomes. Increased accumulation of tyrosine equivalents and $E^{260}$ absorbing substances also occurred (Table 2). These products are known to be liberated by cathepsin and ribonuclease from their respective substrates. Therefore, increased accumulation of these products may be related to quick release of these two enzymes owing to the altered structure of the lysosomes.

The light-scattering properties of purified lysosomes indicated the presence of swollen or injured lysosomes in liver from protein-starved rats and of intact lysosomes in liver from normal rats. This effect was also reflected in the difference in the rate of availability of acid phosphatase.

Differential centrifugation is known to separate large particles at lower speeds (de Duve, Berthet $\&$ Beaufay, 1958). The procedure for isolating lysosomes from normal liver has been modified by reducing the speed during the last two steps of differential centrifugation for obtaining lysosomes from protein-starved liver. Therefore it is possible that only one feeding on a protein-free diet creates changes in the size of rat liver lysosomes and influences their sedimenting characteristics.

Our present studies reveal that the properties of liver lysosomes change after feeding on a protein-free diet from the commencement of the first stage of calorie deficiency. This is indicated by the alterations in sedimenting characteristics, swelling of membrane 
and structural freedom for lysosomal enzymes in homogenates as well as in isolated particles. Vitamin A is reported to influence lysosome structure in vivo and in vitro (Dingle, 1963; Weissmann, 1964). Increased vitamin A alcohol content in the liver after feeding a protein-free diet (Adhikari, Vakil \& Sreenivasan, I968) may be one of the factors responsible for making the lysosome structure labile in protein deficiency.

The liver is capable of meeting a large variety of metabolic situations because the pabulum offered varies with changes in the dietary regimen (Tarver, 1963). According to Tarver (1951), the solution to this problem is evidently met by the liver and the animal in general, by the development of a dynamic system which is particularly interesting in connexion with the metabolism of the protein enzymes. The wide fluctuations in the level of these enzymes as reported by Knox, Auerbach \& Lin (1956) may be due to their continuous synthesis and degradation. The existence of this dynamic system has been demonstrated by Schoenheimer, Ratner, Rittenberg \& Heidelberger (1942). Several investigators (Borsook \& Keighley, 1935; Borsook \& Deasy, I95I; Tarver \& Schmidt, 1942) suggested that a continuation of certain anabolic processes leads to a synthesis of protein in liver and other tissues and to the persistence of the processes whether the animal is fed or starving. The rupture of peptide bonds is catalysed by a variety of peptidases which appear in the secretions that pass into the gut and also intracellularly in liver, probably by lysosomal cathepsins (de Duve, Pressman, Gianetto, Wattiaux \& Appelmans, I955; Finkenstaedt, 1957).

Various physiological and pathological processes known to involve lysosomal enzymes are characterized by extensive cellular breakdown. These include liver necrosis and cirrhosis (de Duve, I959; Pagliaro, Giglio, Moli, Catania \& Cittarrela, I964), regression of tadpole tails (Weber, r963; Zalkin, Tappel, Caldwell, Shibko, Desai \& Holliday, 1962), hypervitaminosis A (Lucy, Dingle \& Fell, 1961), muscular dystrophies (Zalkin et al. r 962), muscular dystrophies and bruises (Hamdy, May \& Powers, I96I), and in vitro digestion of subcellular organelles (Sawant, Desai \& Tappel, 1964). Increased formation of hydrolytic products in homogenates of protein-starved liver are analogous to those which accumulate during autolysis (Cameron \& Spector, 196r). Therefore, increased physiological autolysis may occur when protein deficiency is coupled with calorie deficiency. The relationship between structural freedom for lysosomal enzymes and liver autolysis of protein-starved liver is not yet clear. Nevertheless, our present studies show change in physicochemical properties of lysosomes after only one feeding on a protein-free diet and suggest more complicated events after prolonged deficiency or at a stage of acute inanition.

\section{REFERENCES}

Adhikari, H. R., Vakil, W. K. \& Sreenivasan, A. (1968). Indian F. Biochem. 5, 132.

Anson, M. L. (1938). Y. gen. Physiol. 22, 79.

Borsook, H. \& Deasy, C. L. (195I). A. Rev. Biochem. 20, 209.

Borsook, H. \& Keighley, G. L. (1935). Proc. R. Soc. B I18, 488 ,

Camain, R., Rouiller, Ch. \& Dupin, H. (1959). Ann. Anat. Pathol. 4, 220.

Cameron, R. \& Spector, W. G. (1961). Chemistry of the Cell Injury, p. 197. Illinois: Charles C. Thomas. de Duve, C. (1959). In Subcellular Particles, p. 128. [T. Hayashi, editor.] New York: Ronald Press.

de Duve, C., Berthet, J. \& Beaufay, H. (1958). Progr. Biophys. 9, 325.

de Duve, C., Pressman, B. C., Gianetto, R., Wattiaux, R. \& Appelmans, F. (I955). Biochem. F. 60, 604. 
Dingle, J. T. (1963). Ciba Fdn Symp. on Lysosomes p. 384. [A.V.S. de Reuck and M. P. Cameron, editors.] London: J. \&. A. Churchill Ltd,

Essner, E. \& Novikoff, A. B. (1961). F. Biophys. Biochem. Cytol. 9, 773.

Finkenstaedt, J. T. (1957). Proc. Soc. exp. Biol. Med. 95, 302.

Gadrat, J., Panel, H., Guilhem, A. \& Izard, J. (1960). Path Biol., Paris 8, 697.

Hamdy, M. K., May, K. N. \& Powers, J. J. (196r). Proc. Soc. exp. Biol. Med. 108, 185.

Knox, W. E., Auerbach, V. H. \& Lin, E. C. C. (1956). Physiol. Rev. 36, 164.

Lowry, O. H., Roberts, N. R., Wu, M. L., Hixon, W. S. \& Crawford, E. J. (1954). F. biol. Chem. 207, I9.

Lucy, J. A., Dingle, J. T. \& Fell, H. B. (196I). Biochem. F. 79, 500.

Miller, G. L. (I959). Analyt. Chem. 31, 964.

Narasinga Rao, B. S. \& Radhakrishnan, M. R. (1966). Indian $\mathcal{F}$. med. Res. 3, 40.

Novikoff, A. B. (1961). In The Cell. Vol. 2, p. 442. [J. Brachet and A. E., Mirsky, editors.] New York: Academic Press Inc.

Padwaldesai, S. R., Ninjoor, V., Ramakrishnan, T. V., Sawant, P. L., Kumta, U. S. \& Sreenivasan, A. (1969), Br. $\mathscr{F}$. Nutr. 23,745 .

Pagliaro, L., Giglio, F., Moli, S. L., Catania, A. \& Cittarrela, P. (1964). F. Lab. clin. Med. 63, 977.

Rappaport, A. M. (1963). In The Liver. Vol, I, p. 266. [Ch. Rouiller, editor.] New York: Academic Press Inc.

Sawant, P. L., Desai, I. D. \& Tappel, A. L. (I964). Biochim. biophys. Acta 85, 93.

Sawant, P. L., Shibko, S., Kumta, U. S. \& Tappel, A. L. (I964). Biochim. biophys. Acta 85, 82.

Schoenheimer, R., Ratner, S., Rittenberg, D. \& Heidelberger, M. (1942). F. biol. Chem. 144, 54I.

Tarver, H. (1951). In Amino Acids and Proteins, p. 769. [D. M. Greenberg, editor.] Illinois: Charles C. Thomas.

Tarver, H. (1963). In The Liver. Vol. I, p. 451. [Ch. Rouiller, editor.] New York: Academic Press Inc.

Tarver, H. \& Schmidt, C. L. A. (1942). F. biol. Chem. 146, 69.

Waterlow, J. C. (1959). Nature, Lond. 184, 1875.

Weber, R. (1963). Ciba Fdn Symp. on Lysosomes p. 282 [A. V.S. de Reuck and M. P. Cameron, editors.] London: J. \&. A. Churchill Ltd.

Weissmann, G. (1964). Fedn Proc. Fedn Am. Socs exp. Biol. 23, 1038.

Williams, J. N. Jr (196r). F. Nutr. 73, 210.

Zalkin, H., Tappel, A. L., Caldwell, K. A., Shibko, S., Desai, I. D. \& Holliday, T. A. (г96z). F. biol. Chem. 237, 2678. 